\section{Birlesik Dünya Arastrma Cypriot Journal of Educational \\ Sciences}

Volume 15, Issue 3, (2020) 511-518

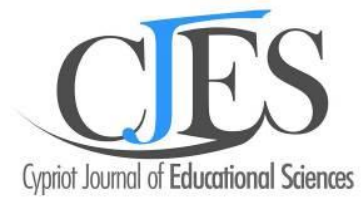

$\underline{\text { www.cjes.eu }}$

\title{
The effect of mindful attention awareness on ruminative thought styles: Physical education and sports teacher candidates
}

\author{
Baris Karaoglu*, School of Physical Education and Sports, Bingol University, 12000 Bingol, Turkey \\ https://orcid.org/0000-0003-3798-9740 \\ Ilimdar Yalcin, School of Physical Education and Sports, Bingol University, 12000 Bingol, Turkey \\ https://orcid.org/0000-0001-8431-6835
}

\section{Suggested Citation:}

Karaoglu B. \& Yalcin I., (2020). The effect of mindful attention awareness on ruminative thought styles: Physical education and sports teacher candidates. Cypriot Journal of Educational Science. 15(3), 511-518. DOI:

$10.18844 /$ cjes.v\%vi\%i.4928

${ }^{\circ} 2020$ United World Center of Research Innovation and Publication. All rights reserved.

\begin{abstract}
The present study aimed to examine the effect of mindful attention awareness on ruminative thought styles levels of physical education and sports teacher candidates. 183 students studying in the Department of Physical Education and Sports Teaching at Bingol University voluntarily participated in the study. Mindful attention awareness and ruminative thought style scale were used as data collection. The scales were applied to students by face-to-face survey method. SPSS package program was used to analyze of the data. Pearson Correlation and Linear Regression analyses were applied for the statistical analyses. As a result, it was found that there was a positive and low-level relationship between mindful attention awareness and ruminative thought styles while mindful attention awareness slightly affected ruminative thought styles. In this context, it can be said that the students do not lose command over past or future events in their lives and act by experiencing the present moment.
\end{abstract}

Keywords: Sports; teacher candidates; mindfulness; ruminative thought

\footnotetext{
* AdDRESS fOR CORRESPONDENCE: Baris Karaoglu, School of Physical Education and Sports, Bingol University, 12000 Bingol, Turkey 
Karaoglu B. \& Yalcin I., (2020). The effect of mindful attention awareness on ruminative thought styles: Physical education and sports teacher candidates. Cypriot Journal of Educational Science. 15(3), 511-518. DOI: 10.18844/cjes.v\%vi\%i.4928

\section{Introduction}

Today, certain new variables such as ego, identity, general self-efficacy, and self-regulation, which have recently begun to be studied and regarded as important, have come into prominence. One of these variables is mindful attention awareness. Mindful attention awareness when an individual adopts a receptive attitude and chooses to think openly about the negative feelings they experience without running away from them or trying to destroy, suppress, and judge them (Germer, 2004). Mindful awareness is the state of living and accepting the experiences in the present moment without being influenced by the past or the future (Bishop et al., 2004). Siegel, Germer, and Olendzki (2009) define mindful attention awareness as a simple path in terms of taking a positive step towards personal development and affiliating oneself with all experiences aimed at reducing pain. According to Germer, Siegel, and Fulton (2005), mindful attention awareness is an opportunity to be fully alive and alert in life. Mindful attention awareness is a skill that allows us to be less passive in the face of ongoing events and it is associated with reducing all levels of suffering and increasing our well-being through our positive, negative, and neutral experiences.

The concept of mindful attention awareness was put forward by Langer and Ngnoumen (2018) and it generally represents the individual demonstrating a high level of focus, calmness and stability and channeling their focus on "what is happening at the moment" in an accepting manner without judgment. Mindful attention awareness enables the individual to self-regulate by taking notice of their behavior and emotions. Individuals who become aware of their feelings can utilize their emotions easier and regulate according to their behavior (Deniz, Erus \& Buyukcebeci, 2017). Individuals with low levels of mindful attention awareness will also have low levels of self-perception and awareness of what is going on in their inner world and surroundings (Brown \& Ryan, 2003).

It is estimated that most people evoke the positive and negative situations in their past, present or future intentionally or unintentionally. While evoking these thoughts partly helps individuals to regulate themselves, it can sometimes be a wearing process as well. Continuously evoking goals towards the future in particular can provide a progress (Martin \& Tesser, 1996). However, it is thought that focusing on negative events in the past, present or future may impact daily life and, consequently, the emotional well-being of the individual negatively. The concept of rumination is defined as individuals being passive in the face of their existing problems, remaining stuck in the past, and evoking repetitive thoughts regarding the potential causes and outcomes of the emotions they experience (Nolen-Hoeksema, 1987). Trapnell and Campbell (1999) divided rumination into two categories as pondering and brooding. The individual focuses on questions such as "why" and "what if", and struggles to overcome their negative emotions (Watkins, 2008). It includes questions of negative self-criticism such as "why do I feel this way?" and "why am i unable to overcome problems?". This situation leads to detachment from the present experience and repetitive thinking of eventuated reality (Ogel, 2012). Individuals who ruminate have more negative thoughts regarding the past, present, and future. These individuals spontaneously and repetitively think about their negative memories, recall negative events, and relive them repeatedly. This is a common situation experienced by individuals, they get stuck with negative thoughts instead of focusing on the positive (Lyubomirsky, Caldwell \& Nolen-Hoeksema, 1998; McFarland \& Buehler, 1998).

There are many studies in the literature on mindful attention awareness (Celik, \& Cetin, 2014; Cengiz, Serdar \& Donuk, 2016; Gulum, 2017; Saricali \& Satici, 2017; Kara \& Ceyhan, 2017; Deniz, Erus \& Buyukcebeci, 2017; Meiklejonh et al., 2012; Schonert-Reichl \& Lawlor, 2010; Sample, 2010) and ruminative thought styles (Graham et al., 2018; Gustavson et al., 2018; Robinson \& Alloy, 2003; Topcu, 2014; Cilali, 2015; Onayli, 2019; Aksoz-Efe, 2018). When the information above is evaluated as a whole, it is observed that the concepts of mindful attention awareness and ruminative thought can 
be effective in different areas of life to various extents. However, no studies were found examining both the mindful attention awareness levels and ruminative ruminative thought styles of physical education and sports teacher candidates. Therefore, it is thought that the present study will provide a different perspective and contribute to the field of Physical Education and Sports. In this context, the present study aims to examine the effect of mindful attention awareness on ruminative thought styles levels of physical education and sports teacher candidates.

\section{Method}

\subsection{Research model}

In the present study, the descriptive survey, which aims to reveal the present situation, and correlational survey methods were used. A descriptive survey model is a study approach that aims to describe a past or present situation as it is. It is aimed to describe the events, individuals or objects included in the study as they are and in their own conditions. These elements are not changed or affected in any way. Correlational survey models are study models that aim to determine the presence and/or degree of covariance between two or more variables (Karasar, 2004).

\subsection{Participants}

183 students selected among 190 students studying in the Department of Physical Education and Sports Teaching at Bingöl University School of Physical Education and Sports using the simple complete census method voluntarily participated in the study. Data was collected from students by face-to-face survey method.

\subsection{Data collection}

The socio-demographic information form, the mindful attention awareness scale, and the ruminative thought style questionnaire were used as data collection tools.

\subsubsection{Demographic information form}

Information regarding the gender, age, grade point average (GPA), grade level, and perceived income status presented below (Table 1).

Table 1. Descriptive statistics of the participants

\begin{tabular}{cccc}
\hline Variables & Categories & $\mathbf{N}$ & \% \\
\hline \multirow{2}{*}{ Gender } & Male & 134 & 73.2 \\
& Female & 49 & 26.8 \\
\hline \multirow{2}{*}{ Age } & $18-21$ & 99 & 54.1 \\
& $22-25$ & 81 & 44.3 \\
& 26 and older & 3 & 1.6 \\
\hline \multirow{2}{*}{ GPA } & $1.25-1.99$ & 10 & 5.5 \\
& $2.00-2.99$ & 129 & 70.5 \\
& $3.00-4.00$ & 44 & 24.0 \\
\hline \multirow{2}{*}{ Grade Level } & $1^{\text {st }}$ year & 50 & 27.3 \\
& $2^{\text {nd }}$ year & 66 & 36.1 \\
& $3^{\text {rd }}$ year & 67 & 36.6 \\
\hline
\end{tabular}


Table 1 shows that $73.2 \%$ of the participants are male while $26.8 \%$ are female, $54.1 \%$ are aged 18 21 while $44.3 \%$ are aged $22-25$ and $1.6 \%$ are 26 and older. 5.5\% of the participants have a GPA of $1.25-$ 1.99 while this ratio is $70.5 \%$ for the $2.00-2.99$ range and $24.0 \%$ for the $3.00-4.00$ range. $27.3 \%$ of the participants are 1 st-year students while $36.1 \%$ are 2 nd-year students and $36.6 \%$ are 3 rd-year students. In terms of the perceived income statuses, it is observed that $23.0 \%$ have low income, $68.3 \%$ have medium income and $8.7 \%$ have a high income.

\subsubsection{Mindful attention awareness scale}

This scale was developed by Brown and Ryan (2003) and adapted to Turkish by Ozyesil et al. (2011). The scale is a 6-point scale (1=Almost Always, 6=Almost Never) and consists of 7 items and one dimension. The Cronbach alpha reliability coefficient calculated to test the reliability of the scale was found as .82. In the current study, this coefficient was found as .72.

\subsubsection{Ruminative thought style scale}

This scale was developed by Brinker and Dozois (2009) adapted to Turkish by Karetepe (2010). The scale is a 7-likert scale ( $1=$ Not Suitable, $7=$ Very Suitable) and consists of 20 items and one dimension. The Cronbach alpha reliability coefficient calculated to test the reliability of the scale was found as .82 . In the current study, this coefficient was found as .89.

\subsection{Data Analysis}

The IBM SPSS 24 (Statistical Package for the Social Sciences) statistical package program was used in the analysis of the data. It was determined that the skewness and kurtosis values of the scales ranged between -1 and +1 (Table 2). Values in this range indicate no excessive deviations from normality (Buyukozturk, 2007). In this context, the data was considered to be normally distributed. Accordingly, Pearson Correlation and Linear Regression analyses were applied.

Table 2. The skewness and kurtosis values of the scale scores

\begin{tabular}{cccc}
\hline Variables & $\mathbf{N}$ & Skewness & Kurtosis \\
\hline Mindful Attention Awareness & 183 & .366 & .993 \\
Ruminative Thought Style & 183 & -.189 & -.364 \\
\hline
\end{tabular}

\section{Results}

In this section, the students' mindful attention awareness and ruminative thought style score averages, the relationship between them and the details of the results based on the impact were presented in the table 3-4-5.

Table 3. Descriptive statistics scores of the mindful attention awareness and the ruminative thought style

\begin{tabular}{ccccc}
\hline Variables & $\mathbf{N}$ & Min & Max & $\overline{\mathbf{X}} \pm$ SD \\
\hline Mindful Attention Awareness & 183 & 29.00 & 115.00 & $57.83 \pm 12.88$ \\
Ruminative Thought Style & 183 & 31.00 & 135.00 & $85.32 \pm 21.45$ \\
\hline
\end{tabular}

Table 3 shows that the participants have a score average of $57.83 \pm 12.88$ from the mindful attention awareness scale and $85.32 \pm 21.45$ from the ruminative thought style scale. 
Karaoglu B. \& Yalcin I., (2020). The effect of mindful attention awareness on ruminative thought styles: Physical education and sports teacher candidates. Cypriot Journal of Educational Science. 15(3), 511-518. DOI: 10.18844/cjes.v\%vi\%i.4928

Table 4. Correlation analysis between mindful attention awareness and the ruminative thought style

\begin{tabular}{lccc}
\hline Variables & & $(1)$ & $(2)$ \\
\hline Mindful Attention Awareness (1) & $\mathrm{r}$ & 1 & \\
& $\mathrm{p}$ & & \\
Ruminative Thought Styles (2) & $\mathrm{r}$ & $.183^{*}$ & 1 \\
$\mathrm{~N}=183 ;{ }^{*} \mathrm{p}<.05$ & $\mathrm{p}$ & .013 & \\
\hline
\end{tabular}

When the result of the pearson correlation analysis was examined, it was determined that there was a low-level relationship between mindful attention awareness and the ruminative thought style $(r=-.183 ; p=.013)$.

Table 5. The effect of mindful attention awareness on ruminative thought styles

\begin{tabular}{lccccc}
\hline Dependent Variable: Ruminative Thought Styles & & & & \\
\hline Variables & $\mathbf{B}$ & Standard Error & $\boldsymbol{\beta}$ & $\mathbf{t}$ & $\mathbf{p}$ \\
\hline (Constant) & 48.471 & 3.860 & & 12.557 & .000 \\
Mindful Attention Awareness & .110 & .044 & .183 & 2.501 & .013 \\
$\mathrm{R}^{2}=.033 ;$ adj: $\mathrm{R}^{2}=.028$ & & & & & \\
$\mathrm{~F}=6.255 ; \mathrm{p}=.013$ & & & & & \\
\hline
\end{tabular}

When the results of linear regression analysis was examined, it was found that the level of mindful attention awareness predicted the variable of the ruminative thought styles approximately at the rate of $3 \%$ (adj. $R^{2}=.028$ ). In other words, it was determined that mindful attention awareness affects the ruminative thought styles variable statistically significantly $(\beta=.183 ; p=.013)$.

\section{Discussion}

In this study, which was conducted to determine the effect of mindful attention awareness on ruminative thought style, it was found that participating students had a score average of $57.83 \pm 12.88$ from the mindful attention awareness scale and a mindful attention awareness level above average. When the literature is examined, it is observed that participants had mindful attention awareness levels above average in the studies conducted by Kilincoglu (2020) on university students, by Ozgun (2018) on high-school principals and by Akkaya (2019) on classroom teachers. These findings are in parallel with the results of the present study. Considering that the possible total score from the mindful attention awareness scale ranges between 15 and 90 (Brown \& Ryan, 2003), it can be said that the participants act with awareness towards internal and external events in the face of "what is happening at the moment".

When the score average of the ruminative thought style was examined, it was calculated as $85.32 \pm 21.45$ and it was determined that the participants had ruminative thought levels above average. In the literature study on the aforementioned average scores, it was found that participants had ruminative thought levels above average in the studies conducted by Lale (2019) on university students and by Cakir (2019) on individuals. These findings are in parallel with the results of the present study. It can be said that the participants tend to have ruminative thoughts, repetitively think about negative memories, recall negative events, and relive them in their minds over and over.

When the correlation and regression analysis results were examined, it was observed that mindful attention awareness predicted the ruminative thought styles variable by $3 \%$ and it was determined that there was a positive relationship between mindful attention awareness levels and ruminative thought style. Ruminative thought increases the impact of emotions on thoughts and affects the 
individual's evaluation and interpretation of present situations in a depressive manner. Thus, the individual uses negative thoughts and memories more frequently. When the literature is examined, in the study conducted by Yazici (2020) on university students; a negative, moderate and significant relationship was determined between the score averages of mindful attention awareness and ruminative thought styles. According to this, it can be said that individuals with high levels of mindful attention awareness are expected to have low levels of ruminative thought and that high score averages of mindful attention awareness indicate low score averages of ruminative thought. Individuals in a state of mindful attention awareness become aware of the stimuli perceived by their sensory system without making any evaluations or judgment and, therefore, establish a real connection (Brown \& Ryan, 2003). This connection allows the individual to experience the present moment (Brown, Ryan \& Creswell, 2007). Individuals in a state of mindful attention awareness are peaceful, happy, and aware towards internal and external events. This type of individual knows how to define and evaluate emotions and thoughts. They are both consciousness itself and the observer of consciousness. In other words, these individuals can simultaneously focus on present events without judgment while experiencing them. The aim is not to engage in a certain thought or drive that thought away from oneself, but to be aware of it (Kabat-Zinn \& Hanh, 2009).

\section{Conclusion}

It was found that there was a positive and low-level relationship between mindful attention awareness levels and ruminative thought styles while mindful attention awareness levels slightly affected ruminative thought styles. In this context, it can be said that the students do not lose command over past or future events in their lives and act by experiencing the present moment.

\section{Recommendations}

Since there is a limited number of previous studies on mindful attention awareness and ruminative thought in the literature, more studies can be conducted on the said subjects. Conducting more studies on the subject with different sample groups can fill the deficiency in this area and make a bigger contribution to the literature. It may be beneficial to conduct qualitative studies to make indepth evaluations of the mindful attention awareness levels and ruminative thought styles of university students.

\section{References}

Akkaya, O. (2019). Sinif ogretmenlerinin bilincli farkindalik ve umutsuzluk duzeyleri arasindaki iliski [The relationship between conscious awareness and hopelessness levels of classroom teachers]. (Master Thesis). Kirsehir Ahi Evran Universitesi, Sosyal Bilimler Enstitusu, Kirsehir, Turkey.

Aksoz-Efe, I. (2018). Relations among negative life events, getting psychological help, rumination and perceived stress. Ankara University Journal of Faculty of Educational Sciences, 51(2), 95-119. doi:10.30964/auebfd.425619

Bishop, S. R., Lau, M., Shapiro, S., Carlson, L., Anderson, N. D., Carmody, J., \& Velting, D. (2004). Mindfulness: A proposed operational definition. Clinical Psycholog. Science and Practice, 11(3), 230-41. doi:10.1093/clipsy.bph077

Brinker, J. K., \& Dozois, J. A. (2009). Ruminative thought style and depressed mood. Journal of Clinical Psychology, 65(1), 1-19. doi:10.1002/jclp.20542

Brown, K. W., \& Ryan, R. M. (2003). The benefits of being present: mindfulness and its role in psychological wellbeing. Journal of Personality and Social Psychology, 84(4), 822-848. doi:10.1037/0022-3514.84.4.822 
Brown, K. W., Ryan, R. M., \& Creswell, J. D. (2007). Mindfulness: theoretical foundations and evidence for its salutary effects. Psychological Inquiry, 18(4), 211-237. doi:10.1080/10478400701598298

Buyukozturk, S. (2007). Sosyal bilimler için veri analizi el kitabi [Data analysis manual for social sciences]. $7^{\text {th }}$ ed., Ankara, Turkey: Pegem Akademi Yayincilik.

Cakir, G. (2019). Akilli telefon ve sosyal medya kullanimi ile ruminatif dusunce ve surekli kaygi arasindaki iliski [The relationship between smartphone and social media usage with ruminative thinking and trait anxiety]. (Master Thesis). Uskudar Universitesi, Sosyal Bilimler Enstitusu, Istanbul, Turkey.

Celik, D. A., \& Cetin, F. (2014). The role of mindfulness and self-consciousness on interpersonal conflict resolution approaches. Research Journal of Businnes \& Management, 1(1), 29-38. Retrieved from https://dergipark.org.tr/tr/pub/ribm/issue/32460/360963

Cengiz, R., Serdar, E., \& Donuk, B. (2016). Analyzing the level of mindfulness and entrepreneurship of the university students. International Journal of Social Sciences and Education Research, 2(4), 1632-1643. doi:10.24289/ijsser.279006

Cilali, B. (2015). Modeling the associations among sibling relationship quality, co-rumination, rumination, and depression. (Master Thesis). Middle East Technical University, Social Sciences Institute, Ankara, Turkey.

Deniz, M. E., Erus, S. M., \& Buyukcebeci, A. (2017). Relationship between mindfulness and psychological wellbeing: The mediating role of emotional intelligence. Turkish Psychological Counseling and Guidance Association, 47(7), 17-31. Retrieved from https://dergipark.org.tr/tr/pub/tpdrd/issue/42743/515880

Germer, C. (2004). What is mindfulness?. Insight Journal, 22(3), 24-29. Retrieved from https://www.drtheresalavoie.com/userfiles/253125/file/insight germermindfulness.pdf

Germer, C. K., Siegel, R. D., \& Fulton, P. R. (2005). Mindfulness and psychotherapy. New York, U.S.: Guilford.

Graham, B. M., Denson, T. F., Barnett, J., Calderwood, C., \& Grisham, J. R. (2018). Sex hormones are associated with rumination and interact with emotion regulation strategy choice to predict negative affect in women following a sad mood Induction. Fronters in Psychol, 9(937), 1-11. doi:10.3389/fpsyg.2018.00937

Gulum, I. V. (2017). Effects of mindfulness trainings and practices on therapists' personal life: a metasynthesis. Turkish Psychological Counseling and Guidance Association, 7(47), 117-134. Retrieved from https://dergipark.org.tr/en/pub/tpdrd/issue/42743/515896

Gustavson, D. E., Pont, A., Wishman, M. A., \& Miyake, A. (2018). Evidence for transdiagnostic repetitive negative thinking and its association with rumination, worry, and depression and anxiety symptoms: A commonality analysis. Collabra: Psychology, 4(1), 1-18. doi: 10.1525/collabra.128

Kabat-Zinn, J., \& Hanh, T. N. (2009). Full catastrophe living: using the wisdom of your body and mind to face stress, pain, and illness. Boston, U.S.: Delta.

Kara, E., \& Ceyhan, A. A. (2017). Relationship between mindfulness and depression in university students: Mediating role of self-control. Original Article, 6(1), 9-14. Retrieved from https://www.trdizin.gov.tr/publication/show/pdf/paper/TWpNeU16ZzFOUT09

Karasar, N. (2004). Bilimsel arastirma yontemi [Scientific research method]. Ankara, Turkey: Nobel Yayincilik.

Karatepe, H. T. (2010). Ruminatif dusunme bicimi olcegi'nin Turkce'ye uyarlanmasi, gecerlik ve guvenirlik calismasi [Turkish adaptation, validity and reliability of ruminative thought style questionnaire]. (Psychiatry Tpecialty Thesis). Saglik Bakanligi/Bakirköy Prof. Dr. Mazhar Osman Ruh ve Sinir Hastaliklari Egitim ve Arastirma Hastanesi, Psikiyatri Anabilim Dali, Istanbul, Turkey.

Kilincoglu, B. (2020). Universite ogrencilerinde bilincli farkindalik ile mental iyi olusun incelenmesi [The examination of mindfulness and mental well-being on university students]. (Master Thesis). Başkent Universitesi, Saglik Bilimleri Enstitusu, Ankara, Turkey.

Lale, Z. (2019). Universite ogrencilerinin ruminatif dusunme bicimlerinin ve sosyal iyi olma duzeylerinin duygusal zeka duzeyleri ile iliskisi [The relationship between ruuminative thought style and social well-being level of the university students with the emotional intelligence]. (Master Thesis). Erzincan Binali Yildirim Universitesi, Sosyal Bilimler Enstitusu, Erzincan, Turkey.

Langer, E. J., \& Ngnoumen, C. T. (2018). Mindfulness. In D. S. Dunn (Ed.), Frontiers of social psychology. Positive psychology: Established and emerging issues. New York, NY, US: Routledge/Taylor \& Francis Group, 97111. 
Karaoglu B. \& Yalcin I., (2020). The effect of mindful attention awareness on ruminative thought styles: Physical education and sports teacher candidates. Cypriot Journal of Educational Science. 15(3), 511-518. DOI: 10.18844/cjes.v\%vi\%i.4928

Lyubomirsky, S., Caldwell, N. D., \& Nolen-Hoeksema, S. (1998). Effects of ruminative and distracting responses to depressed mood on retrieval of autobiographical memories. Journal of Personality and Social Psychology, 75(1), 166-177. doi:10.1037/0022-3514.75.1.166

Martin, L. L., \& Tesser, A. (1996). Some ruminative thoughts. Advances in social cognition. Hillsdale, U.S.: Erlbaum.

McFarland, C., \& Buehler, R. (1998). The impact of negative affect on autobiographical memory: The role of selffocused attention to moods. Journal of Personality and Social Psychology, 75(6), 1424- 1440. doi: 10.1037/0022-3514.75.6.1424

Meiklejonh, J., Phillips, C., Freedman, M. L., Griffin, M. L., Biegel, G., Roach, A., Frank, J., Burke, C., Pinger, L., Soloway, G., Isberg, R., Sibinga, E., Grossman L., \& Saltzman, A. (2012). Integrating mindfulness training into k-12 education: Fostering the resilience of teachers and students. Mindfulness, 3(4), 291-307. doi:10.1007/s12671-012-0094-5

Nolen-Hoeksema, S. (1987). Sex differences in unipolar depression. Evidence and Theory, Psychological Bulletin, 101(2), 259-282. doi:10.1037/0033-2909.101.2.259

Ogel, K. (2012). Farkindalik (ayrimsama) ve kabullenme temelli terapiler [Therapies based on awareness (discrimination) and acceptance]. Ankara, Turkey: HYB Basim.

Onayli, S. (2019). Emotional reactions to infidelity: Examining the roles of self-compassion, forgiveness, rumination and cognitive appraisal. (Doctoral Dissertation). Middle East Technical University, Social Sciences Institute, Ankara, Turkey.

Ozgun, M. (2018). Lise mudurlerinin bilincli farkindaliklari ile problem cozme becerileri arasindaki iliski [The relationship between the mindfulness and the problem solving abilities of high school principals]. (Master Thesis). Gazi Universitesi, Egitim Bilimleri Enstitusu, Ankara, Turkey.

Ozyesil, Z., Arslan, C., Kesici, S., \& Deniz, M. E. (2011). Adaptation of the mindful attention awareness scale into Turkish. Education and Science, 36(160), 224-235. Retrieved from http://eb.ted.org.tr/index.php/EB/article/view/697/271

Robinson, M. S. \& Alloy, L. B. (2003). Negative cognitive styles and stress-reactive rumination interact to predict depression: A prospective study. Cognitive Therapy and Research, 27(3), 275-297. doi:10.1023/A:1023914416469

Sample, R. J. (2010). Does mindfulness meditation enhance attention? A randomized controlled trial. Mindfulness, 1(2), 121-130. doi:10.1007/s12671-010-0017-2

Saricali, M. \& Satici, S. A. (2017). Shyness as mediating role between mindfulness and psychological vulnerability. Hitit University Journal of Social Sciences Institute, 10(1), 656-670. doi:10.17218/hititsosbil.285121

Schonert-Reichl, K.A. \& Lawlor, M.S. (2010). The effects of a mindfulness-based education program on pre and early adolescents well-being and social and emotional competence. Mindfulness, 1(3), 137-151. doi:10.1007/s12671-010-0011-8

Siegel, R. D., Germer, C. K., \& Olendzki, A. (2009). Mindfulness: What is it? Where did it come from?, Clinical Handbook of Mindfulness. $1^{\text {st }}$ ed., F. Didonna (Ed), New York, U.S.: Springer Publishing.

Topcu, C. (2014). Modeling the relationships among coping strategies, emotion regulation, rumination, and perceived social support in victims of cyber and traditional bullying. (Doctoral Dissertation). Middle East Technical University, Social Sciences Institute, Ankara, Turkey.

Trapnell, P. D., \& Campbell, J. D. (1999). Private self-consciousness and the five-factor model of personality: Distinguishing rumination from reflection. Journal of Personality and Social Psychology, 76(2), 284304.doi:10.1037/0022-3514.76.2.284

Watkins, E. R. (2008). Constructive and unconstructive repetitive thought. Psychological Bulletin, 134(2), 163206. doi:10.1037/0033-2909.134.2.163

Yazici, E. C. (2020). Universite ogrencilerinin bilincli farkindalik duzeyleri ile ruminatif dusunme bicimlerinin cesitli degiskenler acisindan incelenmesi [Examining of university student's mindfulness level and ruminative thinking styles in terms of various variables]. (Master Thesis). Cumhuriyet Universitesi, Egitim Bilimleri Enstitusu, Sivas, Turkey. 